\title{
Heaths with dwarf ericaceous shrubs and Alpine juniper (Juniperus alpina) in the Dinaric Alps: A nomenclatorial and synsystematic re-appraisal
}

\author{
BOŠTJAN SURINA ${ }^{1,2, *}$ \\ ${ }^{1}$ University of Primorska, Faculty of Mathematics, Natural Sciences and Information \\ Technologies, Glagoljaška 8, SI-6000 Koper, Slovenia \\ 2 Natural History Museum Rijeka, Lorenzov prolaz 1, 51000 Rijeka, Croatia
}

\begin{abstract}
The ecology and phytosociology of north-western Dinaric heaths of the association Rhododendro hirsuti-Juniperetum alpinae Horvat ex Horvat et al. 1974 nom. corr. prop. as well as the syndynamics and synsystematics of heaths in the Dinaric Alps are discussed. While the structure (physiognomy) of these stands is very homogenous and dominated by few species, the flora is heterogeneous, since ecotonal areas, where heaths are most frequently developed, represent a contact zone of elements of different syntaxa. Due to an abrupt reduction in pasture activities strong encroachments of shrubs and trees have become common, which additionally contribute to the floristic heterogeneity of the heaths. Although the identification and circumscription together with synecology and synchorology of heaths in general are more or less easily understood and straightforward, their floristic affinities, in relation to structure homogeneity and syndynamics, are complicated, which led to the proposal of several synsystematic schemes depending on interpretation of the relationship between flora and structure of stands. Dinaric heaths are classified into three classes, Erico-Pinetea, Vaccinio-Piceetea and Festuco-Brometea and a classification scheme is proposed together with nomenclatorial revision of the analyzed heaths with dwarf ericaceous shrubs and Alpine juniper (Juniperus alpina) in the Dinaric Alps.
\end{abstract}

Key words: Dinaric Alps, Ericaceae, Juniperus alpina, phytosociology, Rhododendron hirsutum, synsystematics

\section{Introduction}

An accurate and updated vegetation map is an essential tool for successful conservation planning, monitoring and managing biological diversity and other natural resources both within and outside the existing protected areas. In order to delimit areas with various vegetation types accurately, while assigning them to objective categories that can be easily

* Corresponding author, e-mail address: bostjan.surina@prirodoslovni.com

Copyright ${ }^{\circledR} 2013$ by Acta Botanica Croatica, the Faculty of Science, University of Zagreb. All rights reserved. 
recognized in the field and that reliably reflect fundamental biological differences (primarily the floristic composition and physiognomy), we started with detailed vegetation mapping in the Obruč area (Liburnian karst, Dinaric Alps) in north-western Adriatic (Fig. 1), one of the most important plant areas in Croatia (see RANDIĆ 2009). Vegetation studies in the Obruč mountain range were initiated by Croatian botanist Ivo Horvat and resulted in a worked-out vegetation typology (e.g. HoRvAT 1930, 1931, 1938) and a vegetation map (in collaboration mostly with Z. Pelcer, Z. Matan and S. Bertović) of the broader area (HoRVAT 1962).

Based on a vegetation map of Horvat and co-workers (HORVAT 1962), the study area represents a mosaic of forest and non-forest vegetation types where (subalpine) beech forests of the association Polysticho lonchitis-Fagetum (=Fagetum croaticum australe subalpinum) generally prevail. Southern slopes are covered by thermophilic stands of the association Seslerio autumnalis-Fagetum (=Fagetum croaticum australe seslerietosum) and fir-beech stands of the association Omphalodo-Fagetum var. geogr. Calamintha grandiflora (=Fagetum croaticum australe abietetosum) seslerietosum autumnalis. Stony and steep slopes, intercepted with boulders, gravels and cracks, are covered with more or less pure fir stands of the association Calamagrostido variae-Abietetum (piceetosum). Recently, though not included in the vegetation map, beech stands from the summit were segregated into a new beech association Calamagrostido arundinaceae-Fagetum (CEROVEČKI 2009). Among non-forest vegetation types, botanists mapped three syntaxa: (a) mountain pine scrubs with Pinus mugo of the association Hyperico grisebachii-Pinetum mugo var. geogr. Arabis scopoliana (=Pinetum mughi croaticum [p.p.]), (b) dry and stony grasslands of the subassociation Carici humilis-Centaureetum rupestris seslerietosum tenuifoliae (=Cariceto-Centaureetum rupestris [p.p.]), and (c) heaths with Rhododendron hirsutum and Juniperus alpina (=Juniperus communis L. subsp. sibirica (Suter) Čelak., J. nana Willd.; Rhodereto-Juniperetum).

\section{Syntaxonomy of »heaths«}

Besides the many typological and nomenclatorial issues among most of the above-mentioned syntaxa (compare WeBER et al. 2000), we find the synsystematics and syndynamics of stands dominated by hairy Alpenrose (Rhododendron hirsutum), Alpine juniper (Juniperus alpina) and large-leaved willow (Salix appendiculata), although of homogenous structure, the most difficult problem to solve. These heaths are usually established in a phytoclimatic belt which is characterized by the timberline and/or isolated tree lines, within more or less large ecotone areas, once used for pastures but, due to overall changes in the socioeconomic situation, now almost completely abandoned (PoLDINI et al. 2004). As a result, these areas are nowadays exposed to rapid dynamic phenomena and abrupt changes in vegetation cover. The climatogenic timberline in the Liburnian karst exceeds the highest peaks due to the overall relatively low altitude (the highest peak, Mt Snežnik, reaches 1796 $m$ a.s.l.). However, under anthropogenic influence, and rarely due to extreme environmental site conditions (e.g. steep slopes, sites exposed to strong Bora etc.), the man-made limit of the timberline and/or isolated tree, due to pasture and logging economy, might lie considerably lower than the climatogenic one (e.g. WrABER 1997).

HORVAT (1962) found structurally homogenous and ecologically well defined heaths with Rhododendron hirsutum and Juniperus alpina developed on exposed ridges of lower altitude (between 1200-1400 m a.s.1.). He placed them into the association Rhododendro- 
-Juniperetum nanae and afterwards supported this with an incomplete synoptic table (HORVAT et al. 1974, Tab. 135, col. 1, 16 relevés). These stands, according to vegetation map, are more or less frequent in the Obruč (the main ridge, Pakleno, Mts Suhi vrh, Fratar and Gornik), Snježnik (Bjela Škalja and Ceclje area, Medvejci, Planina and Guslice) and Risnjak area above $1200 \mathrm{~m}$ a.s.l. Similar stands were observed on sites with similar ecological conditions in the Slovenian part of the Liburnian karst as well, on the Snežnik plateau, between 1200-1600 m a.s.l., in the area of Gornji Dužovec, Zatrep, Grdobe, Planinc, Ilovca, Stanišče, Ždrocle etc. and mapped as Rhododendro hirsuti-Salicetum appendiculatae.

Structurally similar, but strikingly different in floristic composition are thermophilic stands with Juniperus alpina and Sesleria robusta from the Biokovo mountain range (Croatia, central Dalmatia) described by Domac as Seslerio robustae-Juniperetum sibiricae (DomAC 1962, VRDOLJAK 1983). Besides hosting a considerable number of Dinaric tussock (Seslerion tenuifoliae) and sub-Mediterranean grassland taxa (Satureion subspicatae), these stands are characterized by the absence of Rhododendron hirsutum and other de-alpine taxa. Within these stands, a subassociation - pinetosum dalmaticae - was recognized on the basis of the presence and/or dominance of Pinus nigra ssp. dalmatica, the only real differential taxon for the floristically and structurally based subassociation. On Jahorina mountain range (central part of Bosnia and Herzegovina) BJELČIĆ (1966) placed stands dominated by Juniperus alpina into the association Junipero sibiricae-Semperviretum schlechanii, while similar stands on Mt Bjelasica in Montenegro, developed on somewhat more acidic soils, were studied by LAKUŠIĆ (1966) who at that time recognized two new associations: Roso pendulinae-Juniperetum nanae and Hyperici-Vaccinietum montenegrini. On Vranica mountain range (central Bosnia and Herzegovina), a geologically diverse area characterized by a mixture of calcareous and siliceous bedrocks, LAKUŠŕc et al. (1979) studied more acidophytic (Hyperici-Vaccinetum bosniacum, Vaccinio-Callunetum subalpinum) and relatively basiphytic stands (Aquilegio-Rhododendretum hirsuti, Arctostaphylletum uvae-ursi) dominated by dwarf ericaceous species.

While the structure (physiognomy) of these stands is very homogenous and dominated by few species such as Rhododendron hirsutum, Juniperus alpina, Salix appendiculata, Erica carnea, Calamagrostis varia and Rosa pendulina, the flora is heterogeneous since this ecotonal area represents a contact zone of elements of different syntaxa. Additionally, due to a conspicuous reduction in pasture activities, strong encroachments of phanerophytes have become common contributing to a mixture of floristic composition of stands. Although the identification and circumscription together with synecology and synchorology of the heaths in general are more or less simple and straightforward, their floristic affinities, in relation to structure homogeneity and syndynamics, are complicated, which led to the proposal of several syntaxonomic schemes depending on the interpretation of the relationship of the two aspects, focusing either on the flora (e.g. WALLNÖFER 1993a, 1993b), the structure (e.g. HoRvat 1962, HoRvat et al. 1974, THeURILlat et al. 1995, STANISCI 1997), or both (PoldiNI et al. 2004). TheuRILlat et al. (1995) placed all mountain pine scrubs, regardless of the substrate, into a new class Roso pendulinae-Pinetea mugi, while they classified all the orotemperate heaths into the class Loiseleurio-Vaccinietea. On the other hand, WALLNÖFER (1993a, 1993b) differentiated acidophilic (Vaccinio-Piceetea) and basiphilic mountain pine scrubs (Erico-Pinetea), while acidophilic heaths were included into the class Loiseleurio-Vaccinietea and basiphilic into the class Seslerietea albicantis. In the Apennines (STANISCI 
1997), mountain pine scrubs and formations with Juniperus alpina lack many boreo-alpine elements and were therefore referred to the class Pino-Juniperetea, a class consisting of orophilous communities dominated by conifers in the circum-Mediterranean area. In the Dinaric Alps (e.g. BlEČIĆ 1957, 1958, LAKUŠIĆ 1966, BJELČIĆ 1966, LAKUŠIĆ et al. 1979, ZuPANČIČ et al. 2004, 2006, VuKELIĆ et al. 2008), mountain pine scrubs and dwarf ericaceous scrubs, strongly influenced by the researches of BRAUN-BLANQUET (1931) and HORVAT (e.g. 1938, 1962, 1974), were classified in different subordinate syntaxa into the class Vaccinio-Piceetea without an exception.

In our study we aim to: (1) elucidate the phytosociological characteristics and site conditions of structurally similar but floristically different stands of north-west Dinaric heaths with hairy Alpenrose Rhododendron hirsutum and Alpine juniper Juniperus alpina, (2) identify the potential vegetation cover and syndynamic relationships between the north-west Dinaric heaths and surrounding forest and non-forest vegetation types and (3) to propose a sensible syntaxonomic scheme for the heaths of the Dinaric Alps.

\section{Methods}

In years 2005 and 2011, we recorded 22 relevés dominated by Rhododendron hirsutum and Juniperus alpina in the Liburnian karst (Fig. 1) applying the standard Central-European method (Braun-Blanquet 1928, WesthofF and VAN DER MAAREL 1973, DierschKe 1994). The plot size used for sampling averaged $30 \mathrm{~m}^{2}$ and further details on the phytosociological parameters of sites are given in Appendix I. A complete floristic inventory is given in table 2, while taxa occurring in a single relevé are listed in Appendix II. Coverage index (D\%, e.g.

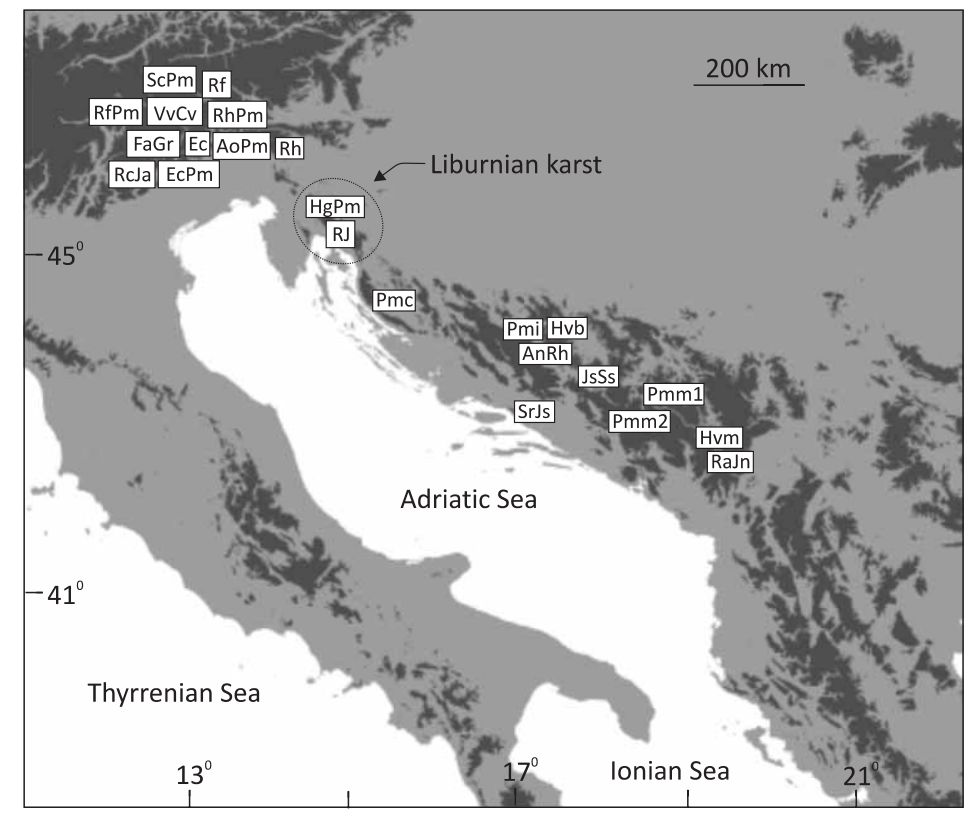

Fig. 1. Map showing the study area (hatched line) and approximate localities of the syntaxa from table 1 with corresponding acronyms. 
Surina 2005) was calculated for each taxon in table 2. The nomenclature and taxonomic source for the names of vascular plants was Mala flora Slovenije (MARTINČIČ et al. 2007). Syntaxonomic groups in tables 2 and 3 were assigned according to Flora Alpina (AESCHIMANN et al. 2004), DAKSKOBler (2006) and Poldini et al. (2004) and the list of syntaxa with full names is given in Appendix III. Prior to numerical analysis, the original cover-abundance values for individual taxa were transformed into an ordinal scale as proposed by van der MAAREL (1979). Groups of vegetation types were ascertained using cluster and ordination analysis with the help of the programme package PAST (HAMMER et al. 2001). The arrangement of relevés in table 2 was done according to the results of cluster analysis (Fig. 2a) and diagnostic groups of species were subsequently tested by means of the SIMPER analysis, an algorithm implemented in programme package PAST. In order to explain the


Fig. 2. The results of (a) cluster (UPGMA), (b) PCA (eigenv.: $1-0.883,2-0.687,3-0.6794-$ 0.695 ; cumulative percentage variance of species-environment relation [in \%]: $1-45.1,2-$ 58.5, 3 - 68.7, 4 - 77.6; (c) ordination (Euclid distances, eigenv.: 1 - 19,7\%, 2 - 12\%, 3 10,5\%; acronyms correspond to those in Fig. 1 and Tab. 1) and (d) DCA (eigenv.: 1 - 0.885, 2 - 0.703, $3-0.759,4-0.585$; cumulative percentage variance of species-environment relation [in \%]: $1-42.8,2-50.0,3-76.9,4-82.2$ ) analysis of stands with dominating Rhododendron hirsutum and Juniperus sibirica in the Liburnian karst (north-west Dinaric Alps) and structurally similar stands from the South-eastern Calcareous and Dinaric Alps. 


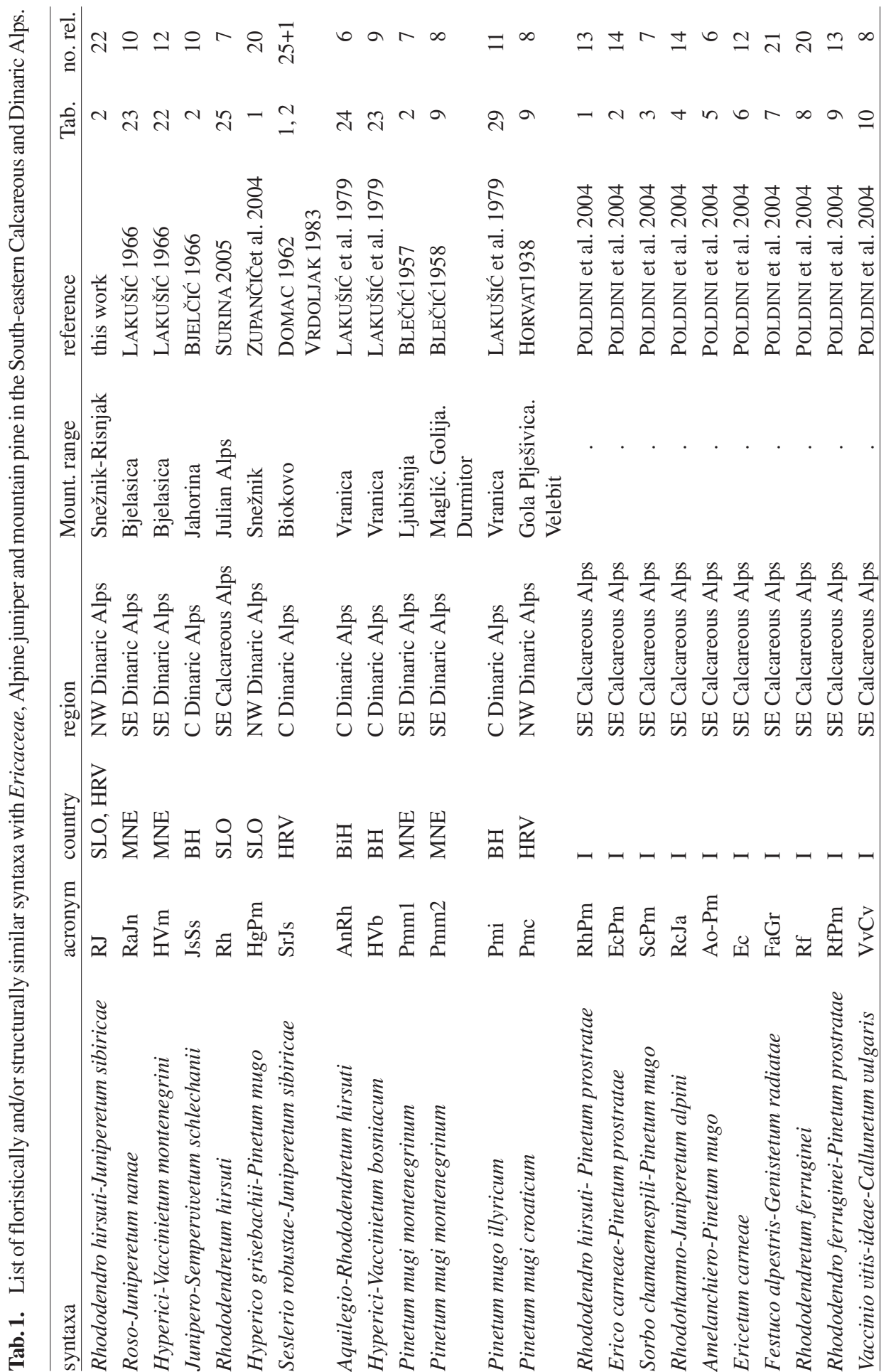


variation by specific environmental and structural (phytosociological) variables, unconstrained (PCA, DCA) and constrained (RDA) ordination analyses were performed, using the CANOCO computer programme (BRAAK TER and ŠMILAUER 2002). In order to determine the lengths of gradients, DCA analyses, detrended by segments, were initially performed and the models (linear, unimodal) used accordingly. The statistical significance of the site parameters $(\mathrm{p}<0.05)$ was tested using the Monte Carlo test, with 499 permutations. Only the significant parameters were then analyzed together, in order to produce a general view of the environmental impact on floristic composition and structure of stands. For estimating the environmental affinities of the relevés, we used Pignatti's indicator values for vascular plants (PIGNATTI 2005). The environmental value in a relevé $\left(\mathrm{EV}_{\mathrm{w}}\right)$ was estimated as the weighted average of the indicator values of all present species, their abundances being used as weights (LEPŠ and ŠMILAUER 2003).

Heaths from the Liburnian karst were compared with mountain pine scrubs and structurally similar stands with dwarf ericaceous scrubs and/or Alpine juniper from other parts of the Dinaric Alps and South-eastern Calcareous Alps between Italy and Montenegro (Tab. 1, Fig. 1).

\section{Results}

Floristic composition and structure of the Liburnian (the north-western Dinaric) heaths

We recorded 98 taxa of phanerogams in 22 relevés with a median number of 27 per relevé ( $\min =17, \max =37$; Tab. 2 ). Coefficient of variation of the number of taxa per relevé is $19.63 \%$. Rhododendron hirsutum ${ }^{+-4}\left(\mathrm{D}_{\%}=7.7\right)$, Juniperus alpina ${ }^{+-4}(6.7)$, Salix appendiculata $^{1-3}(6.4)$ and Calamagrostis varia ${ }^{1-2}(5.4)$ occurred in all relevés with high or the highest coverage of all recorded taxa. Almost one quarter of the all registered taxa occurred in more than $50 \%$ of relevés, with the highest presence and coverage shown by Cyclamen purpurascens $^{+-2}(3.5)$, Rosa pendulina $^{+-2}(3.9)$, Allium ericetorum ${ }^{+-2}(3.7)$, Erica carnea ${ }^{1-4}(4.5)$, Campanula cochleariifolia $^{+-2}$ (2.6), Thesium linophyllum ${ }^{+-2}$ (2.2), Picea abies ${ }^{+-1}$ (1.7), Clematis alpina $^{+-2}(2.2)$ and Aster bellidiastrum ${ }^{+-2}$ (2.5). The structure of stands is defined by their edificators, Rhododendron hirsutum, Juniperus alpina and Salix appendiculata, forming more or less dense scrubby vegetation type not exceeding $1 \mathrm{~m}$ in height. As a rule, these stands are developed on very shallow organogenic soil - lithosol or even over a bare, compact to fragmented limestone bedrock on gravelly slopes of mountain ridges above $1200 \mathrm{~m}$ a.s.l., with long-lasting snow cover where northerly exposed sites prevail. Here, the studied stands are in close contact with subalpine beech (Polysticho-Fagetum), fir-spruce (Calamagrostido-Abietetum) and Dinaric fir-beech forest stands (Omphalodo-Fagetum) as well as with scrubby stands of mountain pine (Hyperico-Pinetum mugo), forming transitions toward forest vegetation types. In frost hollows, an ecologically extreme habitat with specific microsite conditions (e.g. MARTINČIČ 1977, SURINA and VREŠ 2004, 2009, MODRIĆ SURINA and SURINA 2010), the studied stands prefer southerly exposed gravelly slopes and close contact with azonal spruce (Lonicero caeruleae-Piceetum, Hacquetio-Piceetum) and extrazonal subalpine beech forest stands with hairy Alpenrose - Polysticho-Fagetum rhododendretosum (SURINA and RAKAJ 2007), but more frequently with non-forest stands with Carex ferruginea, Salix appendiculata stands, Doronico austriaci-Adenostyletum alliariae, and Drepanoclado uncinati-Heliospermetum pusilli, the last representing the most cryophilic stands developed specifically in frost hollows of north-western Dinaric Alps. 


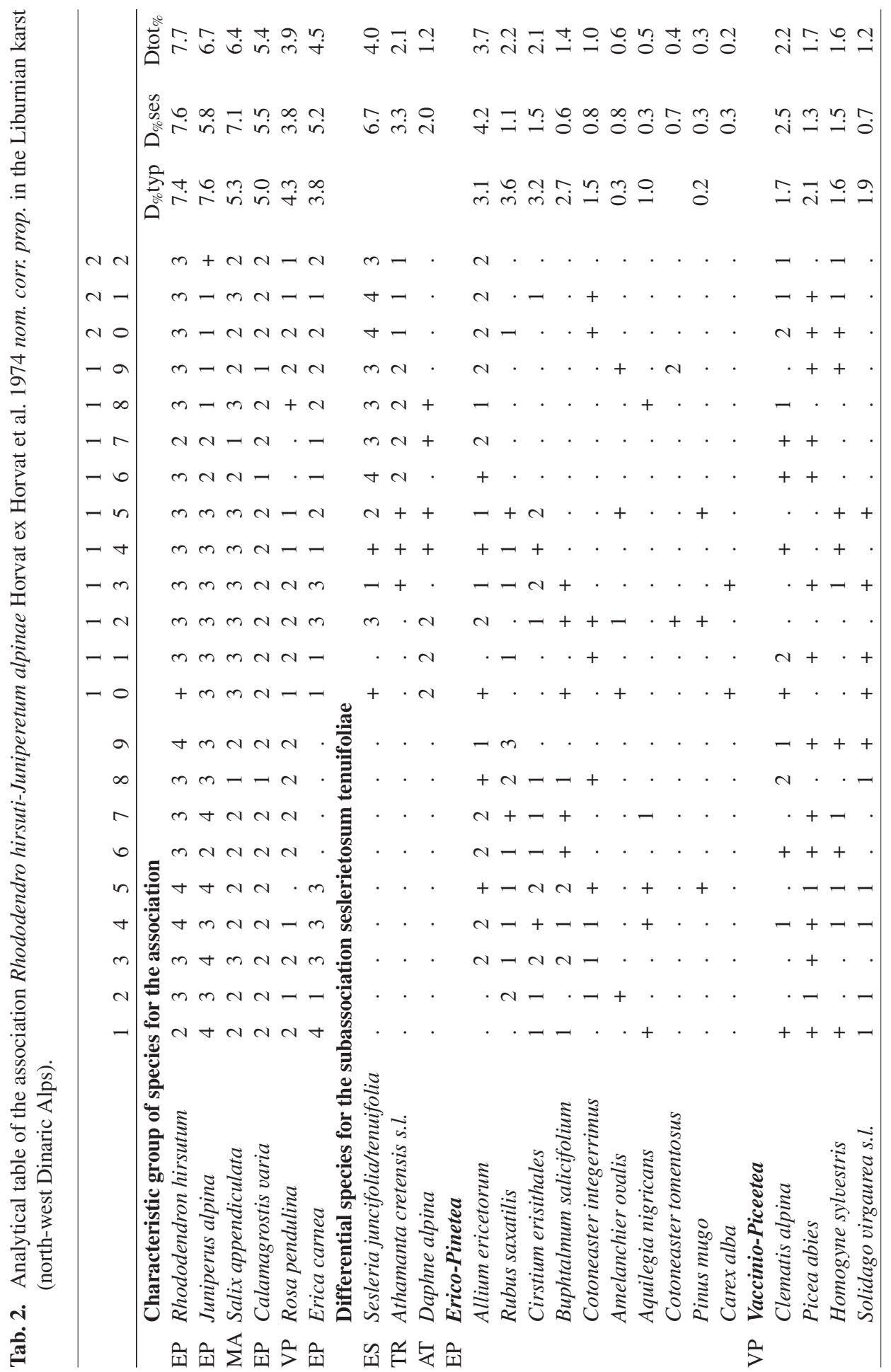









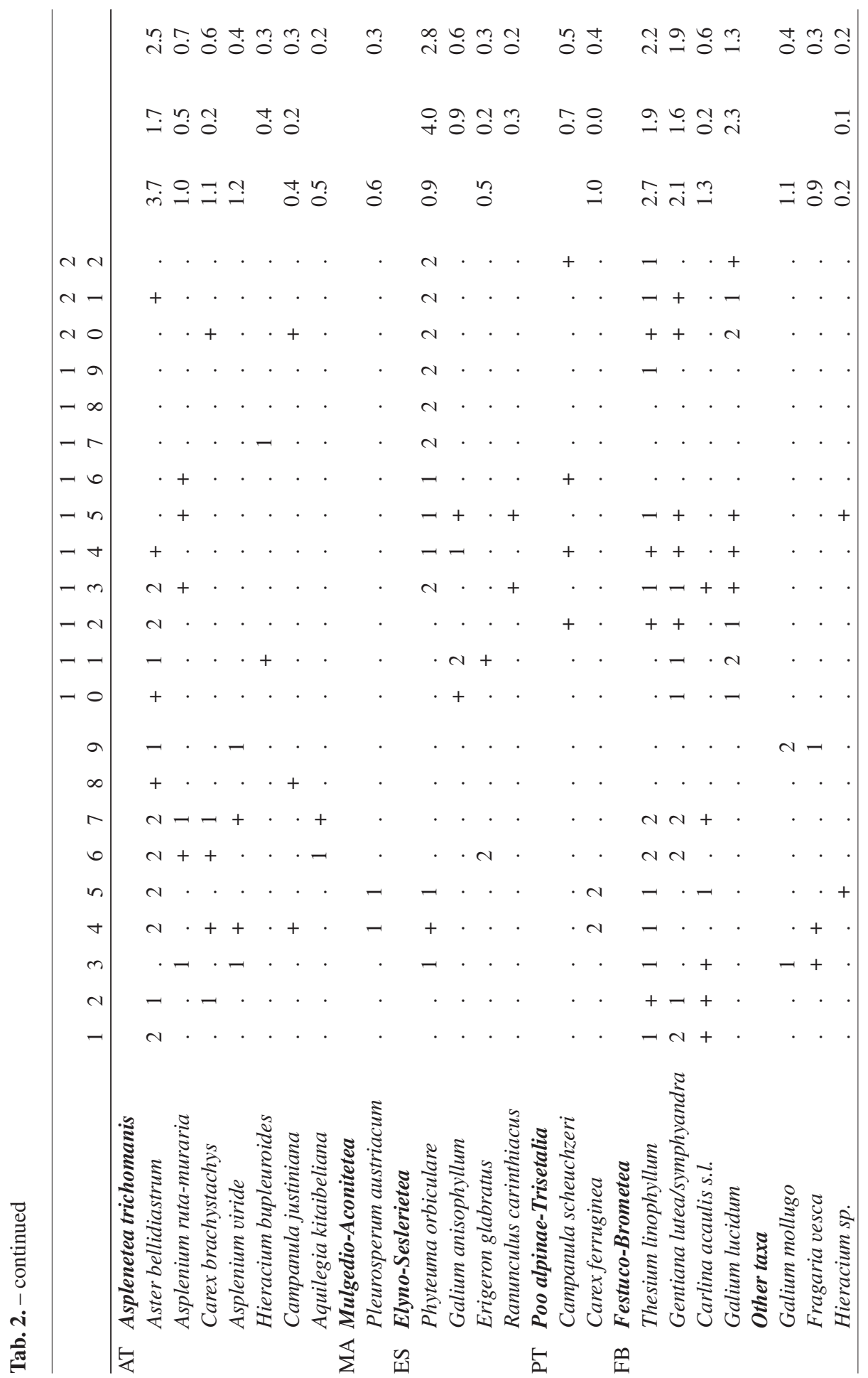


Generally, species of the class Erico-Pinetea completely dominate in stands, being the most frequent and achieving the highest coverage indices $\left(\mathrm{D}_{\%}=44.4\right.$, Tabs. 2,3$)$, followed by spruce forest species (Vaccinio-Piceetea, 15.5) and petrophytic species of screes and rock crevices (Thlaspietea rotundifolii, 9.6 and Asplenietea trichomanis, 6.7, respectively). Dry grassland species of the class Festuco-Brometea (6.2) are represented by six species, the most frequent, occurring in more than $50 \%$ of relevés, being Thesium linophyllum and Gentiana lutea subsp. symphyandra ${ }^{+-2}(1.9)$. There are 11 beech forest species (Fagetalia sylvaticae, 5.2) recorded in the studied stands, but although Cyclamen purpurascens ${ }^{+-2}$ (3.5), occurs in more than $90 \%$ of relevés, the others, a negligible coverage, are much less frequent.

Although structurally very similar, the studied stands form floristically and ecologically two well circumscribed vegetation types (Tabs. 2, 3, Fig. 2 a, b, d). Stands from the first group (»typical« ones) are developed at more elevated, cooler, moister, shadier, sheltered and more nutrient-rich sites. These stands are characterized by higher number and coverage of spruce forest species which is in line with overall lower values for the substrate $\mathrm{pH}$ reaction and cooler sites. On the other hand, stands from the second group (-seslerietosum tenuifoliae) are developed on warmer and lighter sites at lower altitudes but, also thrive on northerly exposed slopes of the ridge, more exposed to strong winds. These stands host a considerably higher number and greater coverage of species preferring open habitats (screes - Thlaspietea rotundifolii, subalpine Dinaric tussock grasslands - Elyno-Seslerietea). Among the phytosociological parameters, the altitude $(\mathrm{P}=0.002)$ and the number of species per relevé $(\mathrm{P}=0.006)$ turned out to be statistically significant factors in floristic differentiation of stands. The first group of stands is clearly separated from the second one along the altitudinal gradient. Results of the SIMPER analysis showed the overall average dissimilarity between the two groups to be 51.84 with the taxa that contributed most to the dissimilar-

Tab. 3. Coverage indices $\left(\mathrm{D}_{\%}\right)$ according to syntaxonomic groups within the association Rhododendro hirsuti-Juniperetum alpinae Horvat ex Horvat et al. 1974 nom. nov. prop. in the Liburnian karst (north-west Dinaric Alps).

\begin{tabular}{lccc}
\hline syntaxa & typical stands & seslerietosum & association \\
\hline Erico-Pinetea & 38.2 & 47.8 & 44.4 \\
Vaccinio-Piceetea & 17.2 & 14.4 & 15.5 \\
Thlaspietea rotundifolii & 6.0 & 11.7 & 9.6 \\
Elyno-Seslerietea & 1.5 & 12.2 & 1.6 \\
Mulgedio-Aconitetea & 7.1 & 7.2 & 7.1 \\
Asplenietea trichomanis & 7.2 & 6.6 & 6.7 \\
Festuco-Brometea & 6.1 & 6.1 & 6.2 \\
Fagetalia sylvaticae & 6.7 & 4.2 & 5.2 \\
Trifolio-Geranietea & 0.7 & 1.9 & 1.4 \\
Querco-Fagetea & 2.1 & 1.1 & 1.4 \\
Poo alpinae-Trisetalia & 1.0 & 0.7 & 0.9 \\
Other taxa & 2.1 & 0.2 & 0.8 \\
Quercetalia pubescentis & 0.7 &. & 0.3 \\
Molinio-Arrhenatheretea & 0.3 &. & 0.1 \\
\hline
\end{tabular}


ity being Sesleria juncifolia subsp. tenuifolia (3.1), Erica carnea (1.8), Phyteuma orbiculare (1.7), Aster bellidiastrum (1.5), Athamanta cretensis (1.5), Rubus saxatilis (1.4) etc. Even the coefficient of variation of the number of taxa per relevé showed differences, being in the first group (»typical« stands) significantly lower (16.5\%) than in the second one $(21.5 \%)$ which might indicate more homogenous floristic composition of stands within the first group. Based on the results of the SIMPER analysis and ecological preferences of taxa in general, as a differential group of species for the second group of stands we chose Sesleria juncifolia subsp. tenuifolia ${ }^{+-4}$ (6.7), Athamanta cretensis $^{+-2}$ (3.3) and Daphne alpina ${ }^{+-2}$ (2), exclusively differentiating the two groups. A taxonomic note: the taxonomic status of specimens of Athamanta cretensis (var. mutellinoides?) from the Liburnian karst is uncertain; specimens at lower altitudes (1000-1300 m) differ morphologically and physiognomically from typical ones found on higher altitude summits (e.g. Mt. Snežnik, 1796 m, or Mt. Snježnik, $1524 \mathrm{~m}$ ), and are similar to specimens of A. haynaldii Borb. et Uechtr.

\section{Syntaxonomic position and notes on nomenclature of Dinaric heaths}

Comparison of the floristic inventory in table 2 and that in the reduced synoptic table 135 in HORVAT et al. (1974) clearly showed that the studied stands belong to the association Rhododendro hirsuti-Juniperetum Horvat 1962. However, in his original diagnosis (HORVAT 1962), the author failed to designate the type relevé (Art. 2b, 7 and 17 of the Phytosociological code), nor did he provide an analytical and/or synoptic table, although subsequently (HoRvat et al. 1974) he did publish a synoptic table (Tab. 135, col. 1), which, according to Art. 7 (WeBER et al. 2000), is the first valid publication of a name (Definition III) Rhododendro hirsuti-Juniperetum alpinae Horvat ex Horvat et al. 1974 nom. corr. prop. (=Rhododendro hirsuti-Juniperetum Horvat 1962 nom. nud.). As a neotype (Definition VIII) we chose a relevé no. 4 in table 2, neotypus hoc loco. Within the studied stands, we recognized a new subassociation Rhododendro hirsuti-Juniperetum alpinae seslerietosum tenuifoliae subass. nova hoc loco, and as a differential group of species for the subassociation we chose Sesleria juncifolia subsp. tenuifolia, Athamanta cretensis and Daphne alpina. Nomenclature type for the new subassociation is relevé no. 17 in table 2, holotypus hoc loco.

Results of the ordination analysis (Fig. 2c) and cluster analyses using various similarity measures (not shown) suggest great floristic similarity between stands of the association Rhododendro hirsuti-Juniperetum from the Liburnian karst (RJ) and stands from the South-eastern Calcareous Alps, belonging to the associations Rhododendro hirsuti-Pinetum prostratae (RhPm), Erico carneae-Pinetum prostratae (EcPm) and Rhododendretum hirsuti (Rh; group A). In all three associations, species from the class Erico-Pinetea prevail both in number and coverage over the species of the other syntaxa and we classified stands from the Liburnian karst into class Erico-Pinetea, order Erico-Pinetalia and alliance Ericion carneae (see below). Stands of the association Aquilegio-Rhododendretum hirsuti (AnRh) were nested in the same group of relevés (Fig. 2c, group A) indicating close floristic and ecological similarity. Hence, we classified them into the alliance Ericion carneae. Although the syntaxon Aquilegio-Rhododendretum hirsuti is supported with the analytical table (Tab. 24 in LAKUŠIĆ et al. 1979), the type relevé has not been designated and is, according to Definition IV of the Code (compare also Articles 5, 15-18), treated as an unpublished name. As a lectotype of the association Aquilegio nigricantis-Rhododendretum hirsuti Lakušić et al. ex 
Surina ass. nova (=Aquilegio -Rhododendretum hirsuti Lakušić et al. 1979 nom. inv.), we chose relevé no. 2 in tab. 24 in LAKUšıć et al. 1979, lectotypus hoc loco.

Dinaric scrubs of Mountain pine (HgPm, Pmc, Pmm 1, 2) formed a group C (Fig. 2c), while more acidophilic syntaxa, either heaths (VvCv, Rf, HVb, HVm, RaJn, JsSs) or mountain pine scrubs (RfPm, Pmi), formed another homogenous group (group B, Fig. 2c). We classified the later, being distinctly acidophilic, into the class Vaccinio-Piceetea, order Vaccinio-Piceetalia and alliance Rhododendro-Vaccinion. The associations Hyperico-Vaccinietum bosniacum, Hyperici-Vaccinietum montenegrinum and Vaccinio-Callunetum subalpinum are invalidly published, violating the principles of phytosociological nomenclature in several articles (e.g. Art. 5, 10, 15-18, 46). Hence, validly published names with selected lectotypes are proposed: Hyperico maculati-Vaccinietum myrtilli Lakušić et al. ex Surina ass. nova (=Hyperico-Vaccinietum bosniacum Lakušić et al. 1979 nom. inv.), lectotypus hoc loco: relevé no. 2 in table 23 in LAKUŠIĆ et al. (1979); Hyperico grisebachii-Vaccinietum myrtilli Lakušić ex Surina ass. nova (=Hyperici-Vaccinietum montenegrinum Lakušić 1966 nom. inv.), lectotypus hoc loco: relevé no. 6 in table 22 in LAKUŠıć (1966); Vaccinio myrtilli-Callunetum vulgaris Lakušić et al ex Surina ass. nova (=Vaccinio-Callunetum subalpinum Lakušić et al. 1979 nom. inv.), lectotypus hoc loco: relevé no. 10 in table 23 in LAKUŠIĆ et al. (1979). According to the results of the analyses, stands of the associations Roso pendulinae-Juniperetum alpinae Lakušić 1966 nom. corr. prop. (Art. 41; =Roso pendulinae-Juniperetum nanae Lakušić 1966) and Sempervivo schlechanii-Juniperetum alpinae Bjelčić 1966 nom. invers. et corr. prop. (Art. 42; =Junipero-Semperviretum schlechanii Bjelčić 1966), gathered in group C together with stands of the associations Hyperico maculati-Vaccinietum myrtilli, Hyperico grisebachii-Vaccinietum myrtilli and Vaccinio myrtilli-Callunetum vulgaris, showed considerable floristic similarities and are thus classified accordingly. For the two mentioned syntaxa, lectotypes were here designated: Roso pendulinae-Juniperetum alpinae Lakušić 1966 nom. corr. prop., lectotypus hoc loco: relevé no. 4 in table 22 in LAKUŠIć (1966); Sempervivo schlechanii-Juniperetum alpine Bjelčić 1966 nom. invers. et corr. prop., lectotypus hoc loco: relevé no. 6 in table 2 in BJELČÍć (1966).

In all the numerical analyses we performed, relevés of the association Seslerio robustae-Juniperetum alpinae Domac 1962 nom. corr. prop. formed a completely separated and floristically clearly distinct group of stands, being the most thermophilic and composed of a significant number of species of the class Festuco-Brometea. Therefore, we omitted this syntaxon from the subsequent analyses and classified it within the class Festuco-Brometea, order Scorzonero-Chrysopogonetalia and alliance Satureion subspicatae.

Erico-Pinetea Horvat 1959

Erico-Pinetalia Horvat 1959

Ericion carneae Rübel ex Grabherr et al. 1993

Aquilegio nigricantis-Rhododendretum hirsuti Lakušić et al. ex Surina ass. nova hoc loco (=Aquilegio-Rhododendretum hirsuti Lakušić et al. 1979 nom. inv.)

Rhododendro hirsuti-Juniperetum alpinae Horvat ex Horvat et al. 1974 nom. corr. prop.

(=Rhododendro-Juniperetum Horvat 1962 nom. nud.)

-seslerietosum tenuifoliae Surina subass. nova hoc loco

Vaccinio-Piceetea Br.-Bl. in Br.-Bl. et al. 1939 emend. Zupančič (1976) 2000

Piceetalia excelsae Pawlowski in Pawlowski et al. 1928

Rhododendro-Vaccinion (Br.-Bl. in Br.-Bl. et Jenny 1926) Br.-B1. 1948

Roso pendulinae-Juniperetum alpinae Lakušić 1966 nom. corr. prop. 


\author{
(=Roso pendulinae-Juniperetum nanae Lakušić 1966) \\ Sempervivo schlechanii-Juniperetum alpinae Bjelčić 1966 nom. invers. et corr. prop. \\ (=Junipero-Sempervivetum schlechanii Bjelčić 1966) \\ Hyperico maculati-Vaccinietum myrtilli Lakušić et al. ex Surina ass. nova hoc loco \\ (=Hyperici-Vaccinietum bosniacum Lakušić et al. 1979 nom. inv.) \\ Hyperici grisebachii-Vaccinietum myrtilli Lakušić ex Surina ass. nova hoc loco \\ (=Hyperici-Vaccinietum montenegrinum Lakušić 1966 nom. inv.) \\ Vaccinio myrtilli-Callunetum vulgaris Lakušić et al. ex Surina ass. nova hoc loco \\ (Vaccinio-Callunetum subalpinum Lakušić et al. 1979 nom. inv.) \\ Festuco-Brometea Br.-B1. et Tx. 1943 \\ Scorzonero-Chrysopogonetalia Horvatić et Horvat (1956) 1958 \\ Satureion subspicatae Horvat 1961 \\ Seslerio robustae-Juniperetum alpinae Domac 1962 nom. corr. prop.
}

\title{
Discussion
}

According to our observations, heaths of the association Rhododendro hirsuti-Juniperetum alpinae persist in sites with extremely low winter temperatures, but with long duration of snow cover, where stands covered with snow are sheltered from low temperature extremes, winter desiccation, ice blast and solar radiation. The same pattern with structurally similar stands on Mt. Jahorina was thoroughly discussed by BJELČIĆ (1966). It seems that in our case extreme winter temperatures on sites with ericaceous heaths are buffered with deep and persistent snowpacks originating either from blasts of snow along the mountain ridges or specific microclimate of frost dolines (temperature inversion!). The specific origin of snowpacks, as well as specifics in relief, are well reflected in floristic composition of stands and distinction of the two subassociations: (a) -typicum, with cryophilic stands developed in moister and cooler sites at the margins or on slopes of frost dolines, and (b)-seslerietosum tenuifoliae, with relatively thermophilic stands developed on warmer, lighter and wind exposed sites on mountain ridges.

Although within a rather restricted area of the Liburnian karst, structurally identical but, in terms of their origin, floristic composition and specifics in site ecology, nevertheless different groups of stands were identified. Due to site ecology and pronounced human impact (deforestation due to intensive logging and subsequent soil erosion and pasture activities), these stands, which are in contact with various forest and non-forest stands, but in general developed within the stands of zonal association Polysticho lonchitis-Fagetum, host a plethora of species of different vegetation types (classes, see POLDINI et al. 2004), rendering synsystematic and syndynamic analyses particularly troublesome. Although there were earlier attempts to explain the origin and syndynamics of studied heaths (e.g. HoRvAT 1962, BJELČIĆ 1966), none of the proposed schemes actually suffice and the question of heath syndynamics, at least in the Dinaric Alps, remains an open question. This is followed with uncertainties in heath synsystematics where several authors proposed various synsystematic schemes based either on floristic principle, structure of stands of both. In our proposal we followed the compromise made by POLDINI et al. (2004), placing heaths on the basis of floristic principle into two classes: Erico-Pinetea and Vaccinio-Piceetea, and only latter, while classifying the associations into the syntaxa ranked bellow the class, took into the consideration their structure. Hence, the Dinaric associations Rhododendro hirsuti-Juniperetum alpinae and Aquilegio nigricantis-Rhododendretum hirsuti (their stands being de- 
veloped on calcareous soils) were placed within the class Erico-Pinetea, while associations Roso pendulinae-Juniperetum alpinae, Sempervivo schlechanii-Juniperetum alpinae (their stands being developed on non-calcareous soils or on sites with close contact to spruce forests, respectively), Hyperico maculati-Vaccinietum myrtilli and Vaccinio myrtilli-Callunetum vulgaris (their stands being developed on non-calcareous soils) within the class Vaccinio-Piceetea. This scheme is well supported by the results of the numerical analyses (Fig. 2c). The association Arctostaphylletum uvae-ursi silicicolum Lakušić et al. 1979 nom. inv., since documented with only a single relevé, was not analyzed, but most probably belongs to the same group of syntaxa. The stands of the association Seslerio robustae-Juniperetum alpinae from the Biokovo mountain range in central Dalmatia, structurally similar, but floristically quite distinct, synsystematically better fit within the class Festuco-Brometea than Erico-Pinetea or even Vaccinio-Piceetea (for further discussion see TrinaJstić 1987) and to ascertain their syntaxonomic position more accurately would require much more comprehensive analyses comparing syntaxa not only of two, but three or four classes. Being aware that their syntaxonomic position is not entirely clear we followed the proposal of TRINAJSTIĆ (1987, 2008), although Sedlar and co-workers placed similar stands with Pinus nigra subsp. dalmatica dominating in a tree layer within the class Pino-Juniperetea (SEDLAR et al. 2011).

Although resolving the syntaxonomy of mountain pine scrubs communities was far beyond the scope of the present paper, the results of our preliminary analyses showed a certain (phyto)geographical structure (Fig. 3c), where Dinaric stands represented a distinct group of syntaxa in all of the performed analyses. However, only a thorough synoptic approach taking into account all the south-eastern-European stands of the Mountain pine would properly challenge their current syntaxonomy.

\section{Acknowledgements}

We thank friends and colleagues Andraž Žnidaršič (Slovenia Forest Service, Slovenia), Andrej Radalj (The Jezero Society, Croatia) for the help during the field work and Željka Modrić Surina (Natural History Museum Rijeka, Croatia), Marko Randić (Public Institution »Priroda «, Croatia), Igor Dakskobler (Science and Research Centre of the Slovenian Academy of Sciences and Arts, Slovenia), Academ. Mitja Zupančič (Slovenian Academy of Sciences and Arts, Slovenia), Emerit. Livio Poldini (University of Trieste, Italy), Romeo di Pietro (Sapienza University of Rome, Italy), Vladimir Hršak and Joco Vukelić (University of Zagreb, Croatia) for fruitful discussions on syntaxonomy of heaths. Special thanks go to Igor Dakskobler for valuable comments and discussions on nomenclatorial issues, while Željka Modrić Surina commented on a previous version of the manuscript. The research was financially supported by the Public Institution »Priroda« (project no. 112-07/11-02/01 -2170-52-01/1-11-19).

\section{References}

Aeschimann, D., Lauber, K., Mosser, D. M., Theurillat, J.-P., 2004: Flora alpina, 1-3. Haupt Verlag, Bern, Stuttgart, Wien. 
BiLlings, W. D., Bliss, L. C., 1959: An alpine snowbank environment and its effects on vegetation, plant developlent, and productivity. Ecology 40, 388-397.

BJELČIĆ, Ž., 1966: Vegetation of the subalpine belt of Mt. Jahorina (in Serbian). Glasnik Zemaljskog muzeja Bosne i Hercegovine u Sarajevu 5, 31-104.

BLEČIć, V., 1957: Contribution to the knowledge of forest vegetation of Mt. Ljubišnja (in Serbian). Glasnik prirodnjačkog muzeja Srpske zemlje, Serija B 10, 25-42.

BLEČIĆ, V., 1958: Forest, scree and rock crevices vegetation of the Piva valley (in Serbian). Glasnik prirodnjačkog muzeja u Beogradu, Serija B, 1-108.

BraAk Ter, J. F. C., Šmilauer, P., 2002: CANOCO Reference manual and CanoDraw for Windows. User's guide to Canoco for Windows: Software for Canonical Community Ordination (version 4.5). Microcomputer Power (Ithaca, NY, USA), New York.

Braun-Blanquet, J., 1928: Pflanzensoziologie. Springer, Berlin.

Braun-Blanquet, J., 1931: Aperçu des groupements végétaux du Bas-Languedoc. Communication S.I.G.M.A. 9, Montpellier.

CEROVEČKI, Z., 2009: Beech forests and milava - As. Calamagrosti arundinaceae-Fagetum (Ht. 1950) Cerovčki as. nov. of the mountain of west Croatia (in Croatian). Šumarski List 133, 417-423

DAKSKOBLER, I., 2006: The association Rhodothamno-Laricetum (Zukrigl 1973) Willner \& Zukrigl 1999 in the Julian Alps (in Slovenian). Razprave 4 Razreda SAZU 57, 117-192.

DierschKe, H., 1994: Pflanzensoziologie. Eugen Ulmer Verlag, Stuttgart.

Domac, R., 1962: Dalmatian Pine (Pinus dalmatica Vis. s.1.) forests on Mt. Biokovo (in Croatian). Acta Botanica Croatica 20-21, 203-223.

Hammer, O., Harper, D. A. T., Ryan, P. D., 2001: Paleontological Statistics Software Package for Education and Data Analysis. Palaeontologia Electronica 4, 1-9.

HoRvat, I., 1930: Vegetation studies in mountains of Croatia. I. Tussoc grassland communities (in Croatian). Rad Jugoslavenske Akademije Znanosti i Umjetnosti 238, 1-96.

HoRvat, I., 1931: Vegetation studies in mountains of Croatia. II. Scree and rock-crevices communities (in Croatian). Rad Jugoslavenske Akademije Znanosti i Umjetnosti 241, 147-206.

HoRvat, I., 1938: Phytosociological research of forests in Croatia (in Croatian). Glasnik za šumske pokuse $6,127-256$.

HoRvat, I., 1962: Mountain vegetation of west Croatia (in Croatian). Acta Biologica II 30, $1-179$.

Horvat, I., Glavać, V., Ellenberg, H., 1974: Vegetation Südosteuropas. Gustav Fischer Verlag, Stuttgart.

LAKUŠIĆ, R., 1966: Grassland vegetation of Mt. Bjelasica (in Serbian). Godišnjak Biološkog Instituta u Sarajevu 19, 25-186.

Lakušić, R., Pavlović, D., ABadžIć, S., Kutleša, L., Mišıć, Lj., RedžIć, S., Maljević, D., Bratović, S., 1979: Ecosystems structure and dynamics on Mt. Vranica in Bosnia (in Serbian). In: RAUš, Du. (ed.), Proceedings 2 Congress of Jugoslavian Ecologists I, 605-714. Savez društava ekologa Jugoslavije, Zagreb.

LEPŠ, J., Šmilauer, P., 2003: Multivariate analysis of ecological data using CANOCO. Cambridge University Press, Cambridge. 
MARTINČIČ, A., 1977: Contribution to the knowledge of the ecology of freezing dolines in Slovenia (in Slovenian). Razprave IV.razreda SAZU 20, 231-316.

Martinčič, A., Wraber, T., Jogan, N., Podobnik, A., Turk, B., Vreš, B., RaVnik, V., FraJman, B., Strgulc KrajšEK, S., TrČAK, B., BačIČ, T., Fischer, M. A., Eler, K., Surina, B., 2007: Small flora of Slovenia. Identification key of vascular plants (in Slovenian). Tehniška založba Slovenije, Ljubljana.

Modrić SurinA, Ž., SuRINA, B., 2010: Snowbed vegetation in Croatia: phytosociology, ecology and conservation status. Plant Biosystems 144, 747-768.

Pignatti, S., 2005: Valori di bioindicazione delle piante vascolari della flora d'Italia. Braun-Blanquetia 39, 1-97.

Poldini, L., Oriolo, G., Francescato, C., 2004: Mountain pine scrubs and heaths with Ericaceae in the south-eastern Alps. Plant Biosystems 138, 53-85.

Randić, M., 2009: Obruč. In: Nikolić, T., Topić, J., Vuković, N. (eds.), Importan plant areas - Croatia (in Croatian), 395-400. Prirodoslovno-matematički fakultet Sveučilišta u Zagrebu i Školska knjiga, Zagreb.

SEDLAR, Z., HRŠAK, V., ŠOŠTARIĆ, R., 2011: Numerical and phytosociological analysis of the Junipero sibiricae-Pinetum dalmaticae Domac (1956) 1965 association and comparison to Mediterranean forests dominated by Pinus nigra Arn. s.l. Šumarski List 85, $139-152$.

STANISCI, A., 1997: Gli arbusteti altimontani dell' Appennino centrale e meridionale. Fitosociologia 34, 3-46.

SuRINA, B., 2005: Subalpine and alpine vegetation of the Krn area in the Julian Alps. Scopolia 57, 1-222.

Surina, B., RAKAJ, M., 2007: Subalpine beech forest with hairy alpenrose (Polysticho lonchitis-Fagetum rhododendretosum hirsuti subass. nova) on Mt. Snežnik (Liburnian karst, Dinaric Mts). Hacquetia 6, 89-102.

SuRINA, B., VREŠ, B., 2004: Phytsociological characteristics of sites of Heliosperma pusillum (=Silene pusilla, Caryophyllaceae) in the freezing ravines on the Snežnik Plateau (SW Slovenia). Razprave 4 razreda SAZU 45, 147-183.

SuRINA, B., VREŠ, B., 2009: The association Drepanoclado uncinati-Heliospermetum pusilli (Arabidetalia caeruleae, Thlaspietea rotundifolii) in the Trnovski gozd plateau (Slovenia, NW Dinaric Mts). Hacquetia 8, 31-40.

Theurillat, J.-P., Aeschimann, D., KüPfER, P., SpIChiger, R., 1995: The higher vegetation units of the Alps. Colloques phytosociologiques 23, 189-239.

TrinAJstić, I., 1987: A sintaksonomic overview of plant communities on Mt. Biokovo (in Croatian). Acta Biokovica 4, 143-174.

TRINAJSTIĆ, I., 2008: Plant communities of Croatia. Akademija šumarskih znanosti, Zagreb.

VAN DER MAAREL, E., 1979: Transformation of cover-abundance values in phytosociology and its effects on community similarity. Vegetatio 39, 97-114.

VRDOLJAK, Ž., 1983: Contribution to the knowledge of forest vegetation of Mt. Biokovo (in Croatian). Acta Biokovica 2, 247-282. 
Vukelić, J., Mikac, S., Baričević, D., BaKšić, D., Rosavec, R., 2008: Forest Sites and Forest Communities in Croatia. National Ecological Network. State Institute of Nature Protection, Zagreb.

WallnöFer, S., 1993b: Erico-Pinetea. In: Grabherr, G., Greimler, J., Mucina, L. (eds.), Die Pflanzengesellschaften Österreichs, 3, Wälder und Gebüsche, 244-282. Fischer Verlag, Jena-Stuttgart-New York.

WallnöFer, S., 1993a: Vaccinio-Piceetea. In: Grabherr, G., Greimler, J., Mucina, L. (eds.), Die Pflanzengesellschaften Österreichs, 3, Wälder und Gebüsche, 283-337. Fischer Verlag, Jena-Stuttgart-New York.

Weber, H. E., Moravec, J., Theurillat, J.-P., 2000: International Code of Phytosociological Nomenclature, 3. Journal of Vegetation Science 11, 739-768.

Westhoff, V., VAN DER MAAREL, E., 1973: The Braun-Blanquet approach. In: WhitTAKER, R. H. (ed.), Ordination and classification of communities. Handbook of Vegetation Science 5, 619-726. Dr. W. Junk b.v. Publishers, The Hague.

Wraber, T., 1997: Bupleurum exaltatum, Mt. Snežnik and - (?) sheeps (in Slovenian). Proteus 59, 374-377.

ZUPANČIČ, M., WrABER, T., ŽAGAR, V., 2004: Dinaric mountain pine association Hyperico grisebachii-Pinetum mugo on Mt. Snežnik (in Slovenian). Razprave 4 razreda SAZU 45, 185-261.

ZupančIČ, M., ŽAgar, V., Culiberg, M., 2006: Slovene Alpine Pinus mugo scrub in comparison with European Pinus mugo scrab. Dela 4 razreda SAZU 40, 1-111.

Appendix I - phytosociological and site parameters of relevés in table 1 (rel. no. and field no., altitude, exposition, inclination, coverage: $\mathrm{S}$ - stoniness, $\mathrm{C}$ - herb layer

1-8 - Mt. Snežnik, 9-22 - Mt. Obruč

1 (20111004/07), 1413 m, NNE, $36 \mathrm{~m}^{2}, 20^{\circ}$, S 40\%, C 60\%, leg. A. Radalj et B. Surina; 2 (20111004/08), 1412 m, SE, $36 \mathrm{~m}^{2}, 10^{0}, \mathrm{~S} \mathrm{60 \% ,} \mathrm{C} \mathrm{40 \% ,} \mathrm{leg.} \mathrm{A.} \mathrm{Radalj} \mathrm{et} \mathrm{B.} \mathrm{Surina;} 3$ (20111004/04), 1390 m, S, $36 \mathrm{~m}^{2}, 25^{0}$, S 60\%, C 40\%, leg. A. Radalj et B. Surina; 4 (20111004/03), 1375 m, NNE, $30 \mathrm{~m}^{2}, 35^{0}$, S 20\%, C 80\%, leg. A. Radalj et B. Surina; 5 (20111004/05), 1400 m, E, $25 \mathrm{~m}^{2}, 40^{0}$, S 30\%, C 70\%, leg. A. Radalj et B. Surina; 6 (20111004/01), $1391 \mathrm{~m}, \mathrm{E}, 20 \mathrm{~m}^{2}, 40^{\circ}$, S 50\%, C 50\%, leg. A. Radalj et B. Surina; 7 (20111004/02), 1400 m, NNE, $25 \mathrm{~m}^{2}, 60^{\circ}$, S 40\%, C 60\%, leg. A. Radalj et B. Surina; 8 (20050724/05), 1340 m, S, $25 \mathrm{~m}^{2}, 20^{0}$, S 30\%, C 70\%, leg. A. Žnidaršič et B. Surina; 9 (20111004/06), 1350 m, NNE, $50 \mathrm{~m}^{2}, 30^{\circ}$, S 40\%, C 60\%, leg. A. Radalj et B. Surina; 10 (20110907/08), 1242 m, ESE, $36 \mathrm{~m}^{2}, 30$, S 40\%, C 60\%, leg. B. Surina; 11 (20110907/12), 1220 m, E, $30 \mathrm{~m}^{2}, 35^{0}$, S 60\%, C 40\%, leg. B. Surina; 12 (20110907/11), 1260 m, NNE, 30 $\mathrm{m}^{2}, 30^{0}$, S 40\%, C 60\%, leg. B. Surina; 13 (20110907/07), 1239 m, N, $25 \mathrm{~m}^{2}, 30^{\circ}$, S 30\%, C $70 \%$, leg. B. Surina; 14 (20110907/06), 1243 m, NNE, $20 \mathrm{~m}^{2}, 30^{0}$, S 40\%, C 60\%, leg. B. 
Surina; 15 (20110907/10), $1248 \mathrm{~m}, \mathrm{~N}, 25 \mathrm{~m}^{2}, 40 \%$, S 50\%, C 50\%, leg. B. Surina; 16 (20110830/10), 1260 m, NNE, $30 \mathrm{~m}^{2}, 25^{0}$, S 60\%, C 40\%, leg. Ž. Modrić Surina et B. Surina; 17 (20110907/05), 1252 m, ENE, $30 \mathrm{~m}^{2}, 30^{0}$, S 60\%, C 40\%, leg. B. Surina; 18 (20110907/09), 1244 m, NNE, $25 \mathrm{~m}^{2}, 35^{0}$, S 60\%, C 40\%, leg. B. Surina; 19 (20110907/04), $1260 \mathrm{~m}, \mathrm{NE}, 50 \mathrm{~m}^{2}, 25^{\circ}$, S 50\%, C 50\%, leg. B. Surina; 20 (20110907/01), $1255 \mathrm{~m}$, ENE, 20 $\mathrm{m}^{2}, 30^{\circ}$, S 40\%, C 60\%, leg. B. Surina; 21 (20110907/02), $1246 \mathrm{~m}$, ENE, $30 \mathrm{~m}^{2}, 35^{\circ}$, S 30\%, C 70\%, leg. B. Surina; 22 (20110907/03), 1250 m, NE, $36 \mathrm{~m}^{2}, 40^{\circ}$, S 40\%, C 60\%, leg. B. Surina.

\section{Appendix II - taxa occurring once in table 1}

Erico-Pinetea: Arctostaphyllos uva-ursi 1 (12), Gymnadenia conopsea + (18), Peucedanum austriacum s.l. + (8); Vaccinio-Piceetea: Huperzia selago + (4), Luzula sylvatica + (4); Fagetalia sylvaticae (incl. Aremonio-Fagion*): Hacquetia epipactis* + (8), Euphorbia carniolica + (8), Melica nutans + (8), Dryopteris filix-mas + (9), Scrophularia nodosa + (9), Acer pseudoplatanus + (13); Querco-Fagetea (incl. Quercetalia pubescentis*): Melittis melissophyllum* + (9), Hepatica nobilis + (8); Trifolio-Geranietea: Ligusticum seguerii 2 (11); Thlaspietea rotundifolii: Petasites paradoxus 2 (18), Dryopteris submontana 1 (9), Festuca nitida 1 (9), Scrophularia laciniata $+(10)$, Trisetum argenteum $+(4) ;$ Asplenietea trichomanis: Asplenium fissum + (6), Kernera saxatilis $+(6)$, Cystopteris fragilis $+(9)$; Mulgedio-Aconitetea: Viola biflora + (6), Aconitum ranunculifolium + (9), Hypericum maculatum ssp. maculatum + (9), Veratrum album s.1. + (3), Tephroseris ovirensis + (4); Elyno-Seslerietea: Polygala alpestris ssp. croatica $+(20)$; Festuco-Brometea: Teucrium montanum + (10), Ruta divaricata 1 (10); Molinio-Arrhenatheretea: Leontodon hispidus 1 (4).

\section{Appendix III - list of syntaxa mentioned in text and table 1}

Amelanchiero-Pinetum mugo Minghetti in Pedroti 1994; Aquilegio nigricantis-Rhododendretum hirsuti Lakušić et al. ex Surina ass. nova hoc loco (=Aquilegio-Rhododendretum hirsuti Lakušić et al. 1979 nom. inv.); Arctostaphylletum uvae-ursi Lakušić et al. 1979 nom. inv:; Aremonio-Fagion (Horvat 1938) Borhidi in Török, Podani et Borhidi 1989; Asplenietea trichomanis Br.-Bl. in Meier et Br.-B1. 1934; Berberido creticae-Juniperion foetidissimae Brullo et al. 2001; Calamagrostido arundinaceae-Fagetum Cerovečki 2009; Calamagrostido variae-Abietetum Horvat 1950 piceetosum; Carici humilis-Centaureetum rupestris Horvat 1931 seslerietosum tenuifoliae Horvat 1962 nom. nud.; Doronico austriaci-Adenostyletum alliariae Horvat ex Horvat 1974;

Drepanoclado uncinati-Heliospermetum pusilli Surina et Vreš 2004; Elyno-Seslerietea Br.-B1. 1948; Ericetum carneae Rübel 1911; Ericion carneae Rübel ex Grabherr et al. 1993; Erico carneae-Pinetum prostratae Zötl 1951 nom. inv.; Erico-Pinetea Horvat 1959; Erico-Pinetalia Horvat 1959; Fagetalia sylvaticae Pawlowski in Pawlowski et al. 1928; Festuco-Brometea Br.-Bl. et Tx. 1943; Festuco alpestris-Genistetum radiatae Peer ex Poldini et al. 2004; Hacquetio-Piceetum Zupančič (1980) 1999; Hyperico maculati-Vaccinietum myrtilli Lakušić et al. ex Surina ass. nova hoc loco (=Hyperici-Vaccinietum bosniacum Lakušić et al. 1979 nom. inv.); Hyperico grisebachii-Vaccinietum myrtilli Lakušić ex Surina ass. nova hoc loco (=Hyperici-Vaccinietum montenegrinum Lakušić 1966 nom. inv.); 
Hyperico grisebachii-Pinetum mugo Wraber et al. in Zupančič et al. 2004 var. geogr. Arabis scopoliana (=Pinetum mughi croaticum Horvat 1938 p.p.; Pinetum mughi montenegrinum Blečić 1957 nom. inv.); Juniperetalia haemisphaericae Rivas-Martinez et Molina 1999; Junipero sibiricae-Semperviretum schlechanii Bjelčić 1966 (=Sempervivo schlechanii-Juniperetum sibiricae Bjelčić 1966 nom. invers. prop.); Lonicero caeruleae-Piceetum Zupančič (1980) 1999; Loiseleurio-Vaccinietea Eggler ex Schubert 1960; Mulgedio-Aconitetea Hadač et Klika in Klika et Hadač 1944; Molinio-Arrhenatheretea R. Tx. 1937 em. R. Tx. 1970; Omphalodo-Fagetum (Tregubov 1957 corr. Puncer 1980) Marinček et al. 1993 var. geogr. Calamintha grandiflora Surina 2001 seslerietosum autumnalis nom. nud. (=Fagetum croaticum australe abietetosum Horvat 1938, Abieti-Fagetum dinaricum Tregubov 1957); Piceetalia excelsae Pawlowski in Pawlowski et al. 1928; Pinetum mughi Illyricum Lakušić et al. 1979 nom. inv.; Pino-Juniperetea Rivas-Martinez 1964; Polysticho lonchitis-Fagetum (Horvat 1938) Marinček in Poldini et Nardini 1993 (=Fagetum croaticum australe subalpinum Horvat 1938) rhododendretosum hirsuti Surina et Rakaj 2007; Poo alpinae-Trisetalia Ellmauer et Mucina 1993; Quercetalia pubscentis Klika 1933; Querco-Fagetea Br.-B1. et Vlieg. 1937; Rhododendretum ferruginei Rübel 1911; Rhododendro ferruginei-Pinetum prostratae Zötl 1951 nom. inv.; Rhododendro hirsuti-Juniperetum sibiricae Horvat ex Horvat et al. 1974 (=Rhododendro hirsuti-Juniperetum sibiricae Horvat 1962 nom. nud.); Rhododendro hirsuti-Pinetum prostratae Zötl 1951 nom. inv.; Rhododendro hirsuti-Salicetum appendiculatae Tomažič nom. nud. (=Salicetum appendiculatae Horvat ex Horvat et al. 1974); Rhododendro-Vaccinion (Br.-Bl. in Br.-Bl. et Jenny 1926) Br.-Bl. 1948; Rhodothamno chamaecisti-Juniperetum alpini Poldini et al. 2004; Roso-Juniperetum nanae Lakušić 1966 (=Roso pendulinae-Juniperetum sibiricae Lakušić 1966 nom. corr.); Roso pendulinae-Pinetea mugi Theurillat in Theurillat et al. 1995; Satureion subspicatae Horvat 1962; Scorzonero-Chrysopogonetalia Horvatić et Horvat (1956) 1958; Seslerio autumnalis-Fagetum (Horvat 1938) M. Wraber ex Borhidi 1963 (=Fagetum croaticum australe seslerietosum autumnalis Horvat 1938); Seslerion tenuifoliae Horvat 1962; Seslerietea albicantis Oberdorfer 1978 corr. Oberdorfer 1990; Seslerio robustae-Juniperetum sibiricae Domac 1962; Sorbo chamaemespili-Pinetum mugo Minghetti 1996; Thlaspietea rotundifolii Br.-Bl. in Br.-Bl. et Jenny 1926; Trifolio-Geranietea Th. Mueller 1961; Vaccinio myrtilli-Callunetum vulgaris Lakušić et al. ex Surina ass. nova hoc loco (Vaccinio-Callunetum subalpinum Lakušić et al. 1979 nom. inv.); Vaccinio-Piceetea Br.-Bl. 1939 emend. Zupančič (1976) 2000; Vaccinio vitis-ideae-Callunetum vulgaris Poldini et al. 2004. 